\title{
Mechanism for Handling of Criminal Action Prohibiting the Use of Land Without Permission
}

\section{Dwi Anas Rudiyantoro*) and Sri Kusriyah ${ }^{* *}$}

*) Student of Master of Law, Faculty of Law, Universitas Islam Sultan Agung Semarang, E-mail: anasraditya7@gmail.com

${ }^{* *}$ Faculty of Law, Universitas Islam Sultan Agung Semarang

\begin{abstract}
.
The aim of this research is; to find out and analyze the mechanism for handling criminal cases prohibiting the use of land without a permit. Toknow and analyze obstacles in handling criminal cases prohibiting the use of land without a permit. To know and analyze solution to overcome the problem of handling criminal cases prohibiting the use of land without a permit. This study uses a sociological juridical approach, with descriptive analytical research specifications. The results of this study are the mechanism for handling criminal cases prohibiting the use of land without a permit contains the procedures and procedures for handling, terminating and settling Police Reports up to the District Court level. Constraints, namely: a) Limited police investigator personnel. b) Lack of facilities and facilities. c) Lack of police expertise in handling criminal cases of land grabbing. d) Difficulty in calling witnesses. e) Difficulty finding expert information. f) The old reporting party reports to the police after the crime has occurred. The solution is a) Adding personnel to the investigation team at the Cirebon City Police Reskrim Unit I. b) Conducting a coordination relationship between the Cirebon City Police and the Cirebon City National Land Agency. c) Conduct a search for heirs and visit the witness's domicile.
\end{abstract}

Keywords: Mechanism; Crime; Prohibition of Using Land without Permit.

\section{Introduction}

The existence of land cannot be separated in human life. As stated by Adrian Sutedi, in human life, the existence of land cannot be separated from all human actions, because land is a place for humans to carry out and continue their life. ${ }^{1}$

Land in the family tradition has become a symbol of the noble relationship between ancestors and owners (heirs), as a means of dialogue with elders or ancestors (who have died), as a sign that their ancestors are always present in their midst. This religious and cultural meaning is reflected in someone's efforts to defend their land rights as if they are defending their life. Structurally, the issue of land rights and / or land use is not only related to the problem of inequality of ownership structure and distribution patterns, but has touched on the issue of legal efforts to defend community rights to interests which are transferred by regional policy makers as an effort to increase local revenue (PAD) or development in general. ${ }^{2}$

The use of the land must be adjusted to its nature, purpose and condition so that it benefits both the welfare and happiness of those who own it as well as for

\footnotetext{
${ }^{1}$ Sutedi, Adrian. (2007). Peralihan Hak Atas Tanah dan Pendaftarannya. Jakarta: Sinar Grafika. p. 31

2 Husni, Anang. (2009). Hukum, Birokrasi, dan Budaya, Cetakan Kesatu. Yogyakarta: Genta Publishing. p. 2 and 3.
} 
society and the State. The interests of the community and the interests of individuals must balance each other to achieve the main goals, namely prosperity, justice and happiness for the whole people. Soil must be well cared for in order to increase fertility and prevent damage. This obligation to maintain is not only borne by the right holder, but also becomes a burden on any person, legal entity or institution that has a relationship with the land. ${ }^{3}$

In Article 167 paragraph 1 of the Criminal Code which states: Anyone who forces entry into a house, room or closed yard used by another person against the law or is there against the law, and at the request of the rightful or his order does not leave immediately, is threatened with a maximum imprisonment of 9 (nine) months or a maximum fine of IDR 4,500, - (four thousand five hundred rupiah). And it is also regulated in a Government Regulation in Lieu of Act No.51 of 1960 concerning the Prohibition of Use of Land without the Right Permit or Proxy which has now become Act No.51 of 1960.

The aim of this research is to find out and analyze the mechanism for handling criminal cases prohibiting the use of land without a permit. To know and analyze obstacles in handling criminal cases prohibiting the use of land without a permit. Toknow and analyze solution to overcome the problem of handling criminal cases prohibiting the use of land without a permit.

\section{Research method}

This research uses a juridical sociological / sociolegal research approach, where in this research the technical steps taken follow the social science assessment patterns, especially sociology and law. ${ }^{4}$. Type The study in this research is more descriptive in nature, which is a study that is intended to collect information about the status or existing symptoms, namely the state of the symptoms according to what they were when the research was carried out. ${ }^{5}$ The data used in this research is secondary data obtained through library research.

\section{Results and Discussion}

\subsection{Mechanism for Handling Criminal Cases for Prohibiting the Use of Land without a Permit}

In general, land rights are regulated in Act No. 5 of 1960 concerning Basic Agrarian Principles (UUPA). Among the main objectives of the establishment of the Basic Agrarian Law (UUPA), namely to place principles to provide legal certainty regarding land rights. Legal certainty that is meant includes: certainty regarding the legal subject of land (person or legal entity); certainty regarding the location, boundaries, size or area of land or certainty related to the object of rights; as well as certainty regarding the status of land rights which is the foundation of the

\footnotetext{
${ }^{3}$ Santoso, Urip. (2015). Perolehan Hak Atas Tanah. Jakarta: Prenadamedia Group. p. 8

4 Soekanto, Soerjono. (1986). Pengantar Penelitian Hukum. Jakarta: UI Press. p. 60

${ }^{5}$ Arikunto, Suharsimi. (1990). Manajemen Penelitian. Jakarta: Rineka Cipta. p. 309
} 
relationship between land and persons or legal entities. ${ }^{6}$. Thus, to ensure legal certainty by the government, land registration is held in all areas of the Republic of Indonesia based on Article 19 of the Basic Agrarian Law. The administration of land registration is carried out by the Government and its technical implementation is regulated in Government Regulation Number 24 of 1997. The National Land Agency and its implementation are carried out by all heads of land offices at the Regency / city level where the land object is located. ${ }^{7}$

The use of land that violates legal norms and regulations, which in fact still occurs in North Jakarta, certainly hinders the government, so that the implementation of urban planning development plans in the field does not work. The absence of responsibility from the parties who control the land to carry out activities such as selling, building houses and other things, will certainly have a negative impact on the parties concerned, the community and also the state. If we look at it from an orderly perspective, tenure without rights must be followed up in depth. Then if you look at it from a health point of view, some areas are no longer suitable to live in because they are not the place where buildings should be built, they will even become a den of various diseases. ${ }^{8}$

Confiscation of land by a person or group of people against other people's land often occurs in various regions in Indonesia. In general, the term land grabbing can be interpreted as an act of controlling, occupying, or taking over other people's land illegally, against rights, or violating applicable legal regulations. Therefore, these acts can be sued according to civil law or prosecuted under criminal law.

Confiscation of land is occupation of land that is already owned by other people. Confiscation of land is regulated in KUHP and Perppu 51/1960, which regulates the prohibition of using land without the rightful permit or legal proxy. The party entitled to the land can take criminal and civil legal steps to ensnare the actions of the village head who helped the land grab process.

The mechanism for handling criminal cases prohibiting the use of land without a permit is as follows:

- The reporter in making a report to prove that the reporter is a person entitled to the land in question by bringing proof of ownership or an original Ownership Certificate / Building Use Rights / Business Use Rights Certificate or other supporting documents to make a Police Report possible.

- If the reporter is unable to prove his / her ownership in the form of an original Ownership Certificate / Building Use Rights Certificate / Business Use Rights Certificate and other supporting letters, the Reporting Party cannot be accepted.

\footnotetext{
${ }^{6}$ Harsono, Boedi. (2005). Hukum Agraria Indonesia, Sejarah Pembentukan Undang-Undang Pokok Agraria. Isi dan Pelaksanaannya. Jakarta: Djambatan.

${ }^{7}$ Kesuma, Derry Angling. (2016). Implementasi Pasal 2 Peraturan Pemerintah Pengganti UndangUndang Nomor 51 Tahun 1960 Tentang Larangan Pemakaian Tanah Tanpa Izin yang Berhak atau Kuasanya. Lex Librum: Jurnal Ilmu Hukum, 3(1).

8 Lowing, Fenia Stepanie Gabriella. (2017). Implementasi Penegakan Hukum Terhadap Penyerobotan Hak Milik Atas Tanah Menurut UU No. 51/PERPU/1960. Lex Et Societatis, 5(1).
} 
- After the report is received and a preliminary examination has been carried out by the officer, the Police Report is delegated to the General Criminal Investigation Unit, especially the Sub-Directorate.

- After the Sub-Directorate receives an abundance of Police Reports investigating the Sub-Directorate, it is not necessary to prove the status of the reporter's ownership of the land object because it has been proven by the reporter himself in the reporting process.

- The investigator immediately conducted an in-depth examination regarding the reported status of using land without the rightful permit or proxy.

- After it is evident that the reported party is using land without the rightful permit or proxy for a piece of land, immediately file the case and submit the case file to the District Court which falls under the criteria for minor crimes.

With the aforementioned steps, it is hoped that the case handling mechanism will not drag on because the investigator focuses on the evidence of the reported party, while the ownership status of the reporter has been proven by himself in the reporting process and the investigator only has to write the facts referred to in the investigation process.

\subsection{Constraints in Handling Criminal Cases Prohibiting the Use of Land without a Permit}

In the UUPA, it is found that the highest right to control land is the right of the nation. We can conclude this is based on the provisions of Article 1 paragraph (1), (2) and (3) which states: (1) the entire territory of Indonesia is the unity of the homeland of all Indonesian people, who have united as the Indonesian nation. (2) The entire earth, water and space, including the natural resources contained therein in the territory of the republic of Indonesia as a gift from God Almighty, is the earth, water and space of the Indonesian nation and constitutes a national wealth. (3) The legal relationship between the Indonesian nation and the earth, water and space referred to in paragraph (2) of this Article is a relationship of a personal nature. ${ }^{9}$

As a form of crime, the existence of a criminal act of land tenure without rights needs to be regulated in a law so that it has legal certainty for criminal responsibility for perpetrators who violate legal provisions regarding land tenure without rights. In view of the foregoing, the matter of land tenure without rights is regulated in the provisions of Article 6 paragraph (1) jo. Article 2 Act No. 51 / PRP / 1960 concerning the Prohibition of Using Land without the Right Permit or Proxy. Article 2 of Act No 51 PRP of 1960 concerning Prohibition of Use of Land without a Rightful Permit or Proxy states that the use of land without the permission of the rightful or legal proxy is a prohibited act, and can be punished with a sentence of imprisonment for 3 (three) month, or a maximum fine of IDR 5.

Lack of legal knowledge of the community includes:

- Not careful (careless) in making purchases of land

\footnotetext{
9 Ma'ruf, Umar. (2006). Politik Hukum Hak Menguasai Oleh Negara Terhadap Tanah, Jurnal Hukum, Vol. 16 No. 3, September, ISSN. 1412-2723, Unissula Semarang
} 
- Ignoring the existence of documentation of land in general and also crossdispute free documentation at the time of purchase of land.

- Abandoning / leaving the land they own, resulting in an encroachment of the land.

Actions of confiscation of land by a person can be processed and charged under the articles contained in Act No 51 PRP of 1960 concerning the Prohibition of Using Land without a Permit and in the Criminal Code, among others: Article of land grabbing (If the perpetrator sells land owned by people other legal documents), Article of Threats (If there is an element of threat in taking over the land, Article of Forgery (If the perpetrator falsifies existing correspondence), Article of Destruction (If the perpetrator destroys plants, fences, stakes belonging to the legal owner, Article Fraud (If any elements of deceiving others with guile and against the law.

Obstacles in handling criminal cases prohibiting the use of land without a permit, namely:

- Limited police investigator personnel

- Lack of facilities and facilities

- Lack of police expertise in handling criminal cases of land grabbing

- Difficulty in calling witnesses.

- Difficulty finding expert information.

- The old reporting party reports to the police after the crime has occurred.

\subsection{Solutions to Overcome Obstacles in Handling Criminal Cases of Prohibiting the Use of Land without a Permit}

National land law, which is based on customary law, adheres to the principle of horizontal separation, that is, land rights do not necessarily include buildings and plants on them. Iman Sudiyat in his book "Hukum Adat Skesta Asas" states that property rights to houses and plants are basically separate from the rights to the land where the objects are located. A person can be the owner of another's house or plant on someone else's land. However, there are restrictions in principle between the rights to plants and houses and the rights to land, such as transactions regarding yards usually include houses and plants. ${ }^{10}$

Indonesia is a country rich in natural resources, one of which is mineral resources which are mostly used as industrial raw materials. The Government of the Republic of Indonesia itself divides the excavated materials into 3 groups, among others: Group A minerals (strategic mining materials), Class B minerals (vital minerals), Group C minerals (non-strategic and non-vital minerals. that so many mineral resources exist in Indonesia. ${ }^{11}$

Islam provides guidance, a reference to the belief in the ummah in providing solutions in the course of life so that humans are able to overcome the problems of

\footnotetext{
${ }^{10}$ Sudiyat, Iman. (2012). Hukum Adat Skesta Asas. Yogyakarta: Liberty, Cetakan ke-7. p. 54.

11 Suroto, Gunarto. Dampak Penambangan Pasir Besi Di Desa Bandungharjo, Banyumanis Dan Ujungwatu Kabupaten Jepara Menurut UU No. 32 Tahun 2009 Tentang Perlindungan Dan Pengelolaan Lingkungan Hidup, Jurnal Daulat Hukum Vol. 1. No. 1 March 2018 ISSN: 2614-560X, Unissula
} 
life in the world and achieve eternal happiness in the hereafter. Waqf is one of the most important teachings in becoming an instrument related to the empowerment of the ummah and solutions to the ummah's economic problems. The birth of Act No 41 of 2004 concerning Waqf marks a new era as well as the seriousness of the government in protecting and supporting the management of waqf assets. Where the Indonesian Waqf Board (BWI) acts as a regulator for the management of waqf assets nationally, it is hoped that it will be able to carry out its duties and functions accountably and professionally. ${ }^{12}$

In the process of investigation or investigation, investigators always use Article 167 paragraph 1 of the Criminal Code which states: Anyone who forces entry into a house, room or closed yard used by another person by violating the law or being there unlawfully, and at the request of the rightful or his order does not leave immediately, is threatened with imprisonment of up to 9 (nine) months or a maximum fine of IDR 4,500, - (four thousand and five hundred rupiah), so that Article 167 of the Criminal Code is categorized as an article regulating land grabbing.

Solutions to Overcome Obstacles in Handling Criminal Cases for Prohibiting the Use of Land without a Permit are:

- Adding personnel to the investigating team at the Unit I City Reskrim Police Unit Cirebon Police

- To coordinate relations between the Cirebon City Police and the Cirebon City National Land Agency

- Conduct a search for heirs and visit the witness's domicile.

\section{Closing}

Based on the description of the data analysis that has been stated, the author tries to draw the following conclusions: The mechanism for handling criminal cases of prohibiting land use without permission contains the procedures for handling, terminating and completing Police Reports up to the District Court level. Obstacles in handling criminal cases prohibiting the use of land without the rightful permission or proxy to enter the compound without permission, namely: a) Limited police investigator personnel. b) Lack of facilities and facilities. c) Lack of police expertise in handling criminal cases of land grabbing. d) Difficulty in calling witnesses. e) Difficulty finding expert information. f) The old reporting party reports to the police after the crime has occurred. Solutions to Overcome Obstacles in Handling Criminal Cases of Prohibiting the Use of Land without Permits are: a) Adding personnel to the investigation team. b) To establish a coordinating relationship between the Police and the National Land Agency. c) To search for heirs and visit the domicile where the witness lives.

Law enforcement officials and the police in particular in handling crimes in the land sector, although they have made good efforts in resolving conflicts and handling them, it should be better to further improve settlement methods that

12 Sumarlan, Analisis Implementasi Undang-Undang Nomor 41 Tahun 2004 Terhadap Legalitas Tanah Wakaf (Studi Di Kantor Kementerian Agama Kota Salatiga), Jurnal Daulat Hukum Vol. 1. No. 1 March 2018 ISSN: 2614-560X, Unissula 
prioritize community approaches. The Land Office should also improve professionalism in conducting more thorough examinations of the completeness of the requirements for parties who wish to apply for land certificates, as well as continue to maintain efforts to prevent crime and make new efforts that can overcome and minimize crimes in the land sector. Local governments should participate in providing support for the prevention of crimes in the land sector and contribute to the protection of land rights for the community, and participate in campaigning and providing real examples to the community of the anti-crime movement, especially in the land sector.

\section{References}

\section{Journals:}

[1] Kesuma, Derry Angling. (2016). Implementasi Pasal 2 Peraturan Pemerintah Pengganti Undang-Undang Nomor 51 Tahun 1960 Tentang Larangan Pemakaian Tanah Tanpa Izin yang Berhak atau Kuasanya. Lex Librum: Jurnal Ilmu Hukum, 3(1).

[2] Lowing, Fenia Stepanie Gabriella. (2017). Implementasi Penegakan Hukum Terhadap Penyerobotan Hak Milik Atas Tanah Menurut UU No. 51/PERPU/1960. Lex Et Societatis, 5(1).

[3] Ma'ruf, Umar. (2006). Politik Hukum Hak Menguasai Oleh Negara Terhadap Tanah, Jurnal Hukum, Vol. 16 No. 3, September, ISSN. 1412-2723, Unissula Semarang

[4] Sumarlan, Analisis Implementasi Undang-Undang Nomor 41 Tahun 2004 Terhadap Legalitas Tanah Wakaf (Studi Di Kantor Kementerian Agama Kota Salatiga), Jurnal Daulat Hukum Vol. 1. No. 1 March 2018 ISSN: 2614-560X, Unissula

[5] Suroto, Gunarto, Dampak Penambangan Pasir Besi Di Desa Bandungharjo, Banyumanis Dan Ujungwatu Kabupaten Jepara Menurut UU No. 32 Tahun 2009 Tentang Perlindungan Dan Pengelolaan Lingkungan Hidup, Jurnal Daulat Hukum Vol. 1. No. 1 March 2018 ISSN: 2614-560X, Unissula

\section{Books:}

[1] Arikunto, Suharsimi. (1990). Manajemen Penelitian. Jakarta: Rineka Cipta.

[2] Harsono, Boedi. (2005). Hukum Agraria Indonesia, Sejarah Pembentukan Undang-Undang Pokok Agraria, Isi dan Pelaksanaannya. Jakarta: Djambatan.

[3] Husni, Anang. (2009). Hukum, Birokrasi, dan Budaya. Cetakan Kesatu. Yogyakarta: Genta Publishing.

[4] Santoso, Urip. (2015). Perolehan Hak Atas Tanah. Jakarta: Prenadamedia Group.

[5] Soerjono, Soekanto. (1986). Pengantar Penelitian Hukum. Jakarta: UI Press.

[6] Sudiyat, Iman. (2012). Hukum Adat Skesta Asas. Liberty. Yogyakarta

[7] Sutedi, Adrian. (2007). Peralihan Hak Atas Tanah dan Pendaftarannya. Jakarta: Sinar Grafika. 